\title{
Photosynthetic characteristics of Trichodesmium in the southwest Pacific Ocean: importance and significance
}

\author{
Italo Masotti ${ }^{1, *}$, Diana Ruiz-Pino ${ }^{1}$, Aubert Le Bouteiller ${ }^{2}$ \\ ${ }^{1}$ Laboratoire d'Océanographie et du Climat, Expérimentations et Approches Numériques (LOCEAN), \\ Institut Pierre Simon Laplace, Université Pierre et Marie Curie, Boîte 134, 4 Place Jussieu, 75252 PARIS Cedex 05, France \\ ${ }^{2}$ Institut de Recherche pour le Développement (IRD), Centre IRD de Nouméa, 101 Promenade Roger Laroque, BP A5 98848, \\ Nouméa, New Caledonia
}

\begin{abstract}
The photosynthetic capacities of Trichodesmium were investigated in a multidisciplinary study comprising 9 cruises in a region of the Coral Sea, southwest Pacific Ocean, where these diazotrophic cyanobacteria are particularly abundant. Thirty specific measurements of photosynthesis in natural communities of Trichodesmium using an $\mathrm{O}_{2}$ electrode with the addition of a ${ }^{14} \mathrm{C}$-tracer gave a mean photosynthetic quotient of 1.19, quite close to the theoretical value. Seven photosynthesis vs. irradiance curves exhibited typically high light-saturated and compensation photosynthetic parameters $I_{\mathrm{k}}$ and $I_{\mathrm{c}}$ (327 and $77 \mu \mathrm{E} \mathrm{m} \mathrm{m}^{-2} \mathrm{~s}^{-1}$, respectively), implying that Trichodesmium requires a stronger irradiance for growth than other phytoplankton typical of oligotrophic systems. The vertical profiles of in situ productivity of Trichodesmium generally showed a maximum at 10 or $20 \mathrm{~m}$ depth and a lower value at the surface, the latter probably being due to photoinhibition. Based on produc-

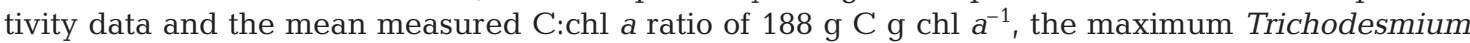
growth rate ranged between 0.18 and $0.32 \mathrm{~d}^{-1}$. The high level of energy required by these organisms to grow could explain why the vertical distribution of Trichodesmium colonies is generally restricted to well-lit surface waters. Furthermore, our observations suggest that the presence of a shallow mixed-layer is a prerequisite for an optimal light regime and a maximum growth rate for this genus. Hence, the seasonal changes in both incident radiation and water column stratification would strongly control the variations in the abundance of Trichodesmium populations, which tends to be minimum in winter and spring and maximum in summer.
\end{abstract}

KEY WORDS: Trichodesmium photosynthesis - Primary productivity · Photosynthetic quotient Cyanobacteria $\cdot$ Marine diazotrophs $\cdot$ Southwest Pacific Ocean

\section{INTRODUCTION}

Trichodesmium is a genus of filamentous non-heterocystous cyanobacteria that is considered responsible for the majority of $\mathrm{N}_{2}$ fixation in the ocean (Capone et al. 2005). The input of biologically available nitrogen to the water column through $\mathrm{N}_{2}$ fixation tends to increase the net primary production and hence the export of particulate organic carbon (POC) to the deep ocean (Karl et al. 2002). Therefore, the $\mathrm{N}_{2}$ fixed by Trichodesmium would contribute to 2 important processes at the global scale: (1) increase in the biological sequestration of atmospheric $\mathrm{CO}_{2}$, thus fuelling the biological pump (Eppley \& Peterson 1979); (2) compensation for the probable imbalance in the modern ocean nitrogen budget due to $\mathrm{N}$ loss by denitrification (Codispoti et al. 2001).

To estimate diazotrophy at the global scale, the main environmental factors that determine the distribution (including bloom formation) and growth of Trichodesmium must be explained, especially in areas 
known to be favourable but poorly documented, such as the southwest Pacific Ocean (LaRoche \& Breitbarth 2005, Campbell et al. 2005). Trichodesmium cells characteristically occur as filaments (trichomes) or colonies (Capone et al. 1997), which at times accumulate massively at the sea surface, producing reddish water, with concentrations up to $10^{5}$ or $10^{6}$ trichomes ${ }^{-1}$ (Sournia 1968, Revelante \& Gilmartin 1982). This organism has most often been reported from regions between $30^{\circ} \mathrm{N}$ and $30^{\circ} \mathrm{S}$ in the 3 major oceans (Capone et al. 2005, LaRoche \& Breitbarth 2005). In the southwest Pacific (SWP), surface blooms have been observed during naval and aerial surveys (Dupouy et al. 2004). Extensive chlorophyll enrichments detected by the Coastal Zone Color Scanner (CZCS; summer 1982) and Seaviewing Wide Field-of-view Sensor (SeaWiFS; summer 1998) that covered surfaces of up to $90000 \mathrm{~km}^{2}$ around New Caledonia were attributed to Trichodesmium (Dupouy et al. 1988). Blooms of Trichodesmium were also reported in the spring-summer period in the Tonga Islands (Bowman \& Lancaster 1965) and in the Great Barrier Reef of Australia, with concentrations of 10000 trichomes $\mathrm{l}^{-1}$ in surface accumulations (Revelante \& Gilmartin 1982). Thus, in contrast to many other large oligotrophic areas of the tropical oceans where these organisms are scarce or totally absent, the SWP appears to be remarkably favourable for Trichodesmium development. Hence, this region is particularly convenient for an investigation of the main physical, chemical and biological processes that control Trichodesmium growth and population dynamics.

Several environmental factors have been suggested to control Trichodesmium growth and $\mathrm{N}_{2}$ fixation, among which are temperature, nutrients such as phosphorus and iron, and light. Trichodesmium growth seems to be favoured in warm seas (LaRoche \& Breitbarth 2005). In the SWP, all Trichodesmium blooms were observed in water in which the temperature exceeded $22^{\circ} \mathrm{C}$ (Dupouy et al. 2004, Moutin et al. 2005). Furthermore, Trichodesmium was shown to be adapted to the low concentrations of available phosphate (Wu et al. 2000). In the SWP, a critical inorganic phosphate concentration as low as $9 \mathrm{nM}$ was required by Trichodesmium populations for maintaining a significant positive growth rate (Moutin et al. 2005). The concentrations of phosphate in that region were observed to be higher than $9 \mathrm{nM}$ in winter and spring, but generally lower than $9 \mathrm{nM}$ in summer and autumn (Van den Broeck et al. 2004). Because most Trichodesmium blooms occur in summer, precisely in the period when inorganic phosphate tends to fall below this critical level (Moutin et al. 2005), this observation suggests that Trichodesmium would have the capacity to utilize other sources of $\mathrm{P}$, such as dissolved organic phosphate (Mulholland et al. 2002).
Considering the aeolian distribution of iron in the ocean and the high iron requirements of Trichodesmium (Berman-Frank et al. 2001), nitrogen fixation by this organism would be iron-limited in large parts of the global ocean (Berman-Frank et al. 2001). However, in the SWP, relatively high iron concentrations (200 to $400 \mathrm{pM}$ ) were observed at 1 station north of New Caledonia by Nakayama et al. (1995); in contrast, Campbell et al. (2005) reported surface iron concentrations that ranged between less than the analytical detection limit of 60 and 320 pM at 4 stations north of New Caledonia. Without any information on in situ iron uptake kinetics, it is difficult to determine when and where the iron needs of Trichodesmium are partially or totally satisfied in the SWP.

As a possible consequence of nutrient stress $(\mathrm{P}, \mathrm{Fe}$ or other), the Trichodesmium growth rate has been reported to be very slow (Mague et al. 1977). However, some recent field studies suggest that Trichodesmium would have a carbon-doubling time ranging from 3 to 5 d (LaRoche \& Breitbarth 2005), which is faster than previously found but significantly slower than the growth rate of most other phytoplankton species estimated in the western equatorial Pacific (Le Bouteiller et al. 2003). Growth rates of Trichodesmium have not been documented in the South Pacific. Assuming the same pattern in the Pacific as in the Atlantic, it is now important to gain an understanding of the formation of widespread and intense blooms by a slow-growing organism such as Trichodesmium.

With only 1 or 2 cellular divisions per week, the control of Trichodesmium photosynthesis and growth by light availability is expected to be preponderant. A number of studies in the Atlantic Ocean (Li et al. 1980, Kana 1993, Carpenter et al. 1993, Roenneberg \& Carpenter 1993, Carpenter \& Roenneberg 1995, Villareal 1995) demonstrated that Trichodesmium spp. are adapted to growing under high levels of irradiance, as shown by a high mean value of the photosynthetic saturation parameter $I_{\mathrm{k}}$ (close to $300 \mu \mathrm{E} \mathrm{m}^{-2} \mathrm{~s}^{-1}$ ). Similarly, the light compensation index $\left(I_{\mathrm{C}}\right)$ is much higher in Trichodesmium spp. (59 to $280 \mu \mathrm{E} \mathrm{m} \mathrm{m}^{-2} \mathrm{~s}^{-1}$ ) than in other

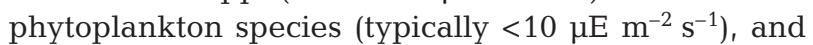
displays highest values at midday and lowest values at night (Kana 1993, Roenneberg \& Carpenter 1993).

The purpose of this study was to describe the photosynthetic characteristics of Trichodesmium in a region where these properties were still unknown, using results of in situ, simulated in situ and laboratory experiments. Results were used to define the optimal light regime required for Trichodesmium growth and to determine whether this light regime could be one of the constraining environmental factors that accounts for the space-time distribution of Trichodesmium in the SWP. 


\section{MATERIALS AND METHODS}

To obtain a robust evaluation of the photosynthetic characteristics of Trichodesmium in the SWP, the photosynthetic capacities of natural populations of Trichodesmium were determined in the laboratory and under in situ and simulated in situ conditions.

Sampling for laboratory and simulated in situ experiments. All sampling was conducted at only 1 location, in Saint Marie Bay (SW New Caledonia lagoon) within an operating area of $1 \mathrm{~km}$ diameter (Fig. 1). The water column (10 to $15 \mathrm{~m}$ depth) of this lagoon area was most often homogeneous. Samples were collected using a $35 \mu \mathrm{m}$-mesh plankton net towed very slowly just under the surface for 1 to several minutes, often crossing slicks of Trichodesmium on the sea surface. The content of the collector was gently poured into a $10 \mathrm{l}$ polycarbonate bottle maintained in the dark, pending its rapid return to the laboratory (within 20 to $30 \mathrm{~min}$ ). On most occasions, the predominant species in these samples was T. erythraeum.

Measurement of photosynthesis vs. irradiance in the laboratory. Seven experiments were carried out in December 2002, in order to obtain photosynthetic production per unit biomass $(P B)$ vs. irradiance $(I)$ curves. Sampling was conducted between 07:00 and 12:00 h. $P B$ is the amount of $\mathrm{O}_{2}$ produced or carbon fixed per hour normalized to chlorophyll a ( $\mathrm{chl} a)$, expressed in $\mathrm{mg} \mathrm{O}_{2} \mathrm{mg} \operatorname{chl~} a^{-1}$ or $\mathrm{mg} \mathrm{C} \mathrm{mg} \mathrm{chl} a^{-1} \mathrm{~h}^{-1}$ ). In the laboratory, freshly collected samples were dispensed into 3 or 4 plastic pails, in order to facilitate the removal of the Trichodesmium colonies coming up to the surface.
After 3 to 6 min, colonies were removed using a micropipette and transferred into a $210 \mathrm{ml}$ glass flask previously filled with the same seawater filtered through a Whatman GF/F filter. The water in the pails was gently stirred every 2 or 3 min to prevent colonies from sticking to the walls, which causes a rapid degradation of the cells. Incubations were carried out in a temperature-controlled laboratory (with mean temperature of $26.0 \pm 0.2^{\circ} \mathrm{C}$ during incubations). The glass flask containing colonies was gently shaken with a magnetic agitator. The flask was closed with a silicone stopper equipped with a microelectrode (Clark type, Unisense) fitted to measure the change in $\mathrm{O}_{2}$ concentration continuously (every $3 \mathrm{~s}$ ), with a $90 \%$ response time of $1 \mathrm{~s}$. The flask was illuminated with 2 light projectors (Osram HLX Xenophot lamp) controlled by a light variator previously calibrated manually for the required intensities using a Biospherical quantum scalar meter QSP-2000. The glass flask was kept in total darkness during the first 5 min of incubation, and then the light intensity $(I)$ was progressively increased every 5 min over the range of 0 to $2200 \mu \mathrm{E} \mathrm{m}^{-2} \mathrm{~s}^{-1}$ (12 to 20 different intensities by experiment), and oxygen production was recorded. The duration of incubation ranged between 75 and $110 \mathrm{~min}$, and the flask content was filtered onto a GF/F filter in order to obtain chl $a$ content via spectrofluorometric analysis.

Analysis of photosynthesis vs. irradiance curves. To calculate the $P B$ vs. $I$ curves and the different photosynthetic parameters, the data points were fitted to an exponential model with the photoinhibition parameter proposed by Platt et al. (1980), using the following algorithms:

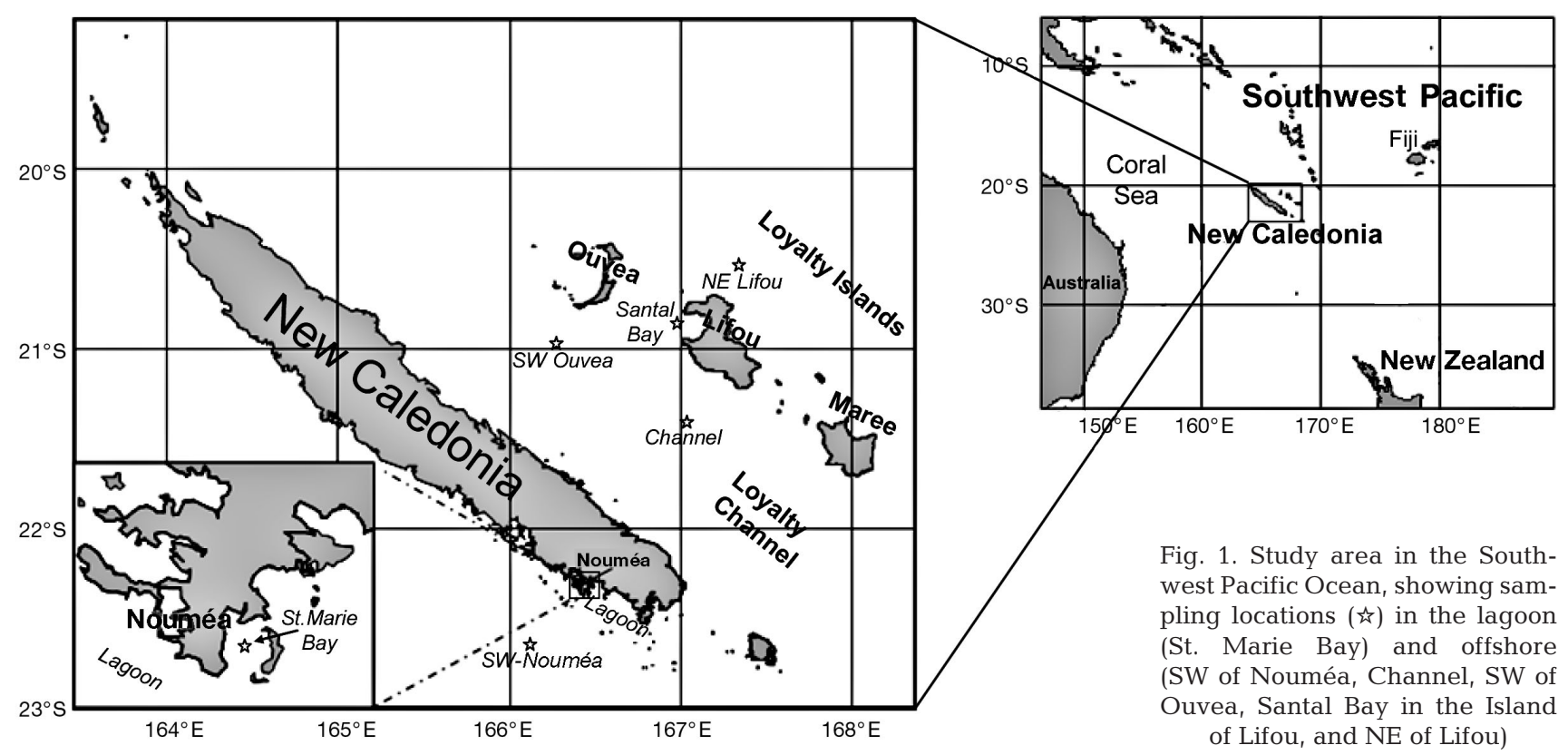




$$
\begin{gathered}
P B=\left\{P_{\mathrm{s}}\left[1-\exp \left(-\alpha I / P_{\mathrm{s}}\right)\right]\left[\exp \left(-\beta I / P_{\mathrm{s}}\right)\right]\right\}-R \\
P_{\text {max }}^{B}=P_{\mathrm{s}}[\alpha /(\alpha+\beta)][\beta /(\alpha+\beta)]^{\beta / \alpha}
\end{gathered}
$$

where $P_{\mathrm{s}}$ is the scaling parameter defined as the maximum potential light-saturated photosynthetic rate; $\alpha$ is the photosynthetic efficiency measured by the initial slope of the $P B$ vs. $I$ curve; $\beta$ is the photoinhibition index and characterizes the negative slope of the curve for high light irradiances (Platt et al. 1980); $R$ is the rate of dark respiration, which was added to Platt's equation to obtain the net photosynthesis; $P^{B}{ }_{\max }$ is the maximum photosynthetic rate, equivalent to $P_{\mathrm{s}}$ when $\beta=0$; $I_{\mathrm{k}}$ is the irradiance saturation parameter, defined as irradiance at the junction of the initial slope and $P^{B}{ }_{\text {maxi }}$ and $I_{\mathrm{C}}$ is the irradiance compensation point and was calculated by setting $P B=0$ in Eq. (1). All rates were normalized to the chl a content of the colonies.

Measurement of the photosynthetic quotient in the laboratory. The photosynthetic quotient (PQ) was measured during 30 specific experiments conducted between 19 November and 12 December 2003, using the oxygen method with the addition of a ${ }^{14} \mathrm{C}$ tracer. ${ }^{14} \mathrm{C}$-bicarbonate $(185 \mathrm{kBq})$ was injected into the $210 \mathrm{ml}$ glass flask through the stopper adapted to the $\mathrm{O}_{2}$ microelectrode. Experimental conditions were similar to those of the $P B$ vs. $I$ experiments, except that light intensity was fixed at $1000 \mu \mathrm{E} \mathrm{m}^{-2} \mathrm{~s}^{-1}$. Incubation duration was $1 \mathrm{~h}$ and $\mathrm{O}_{2}$ concentration was recorded every $10 \mathrm{~s}$. During the first $5 \mathrm{~min}$ of incubation, colonies were

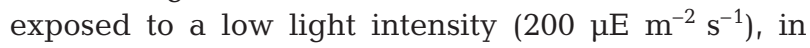
order to verify the good physiological state of the cells. After incubation, samples were processed as for in situ ${ }^{14} \mathrm{C}$ production measurements (see below). The chl $a$ content was measured in duplicate $210 \mathrm{ml}$ samples.

In situ and simulated in situ primary production measurements. In situ measurements were carried out during DIAPALIS cruises as part of the DIAPAZON programme (DIAzotrophy PAcific ZONe, 2001 to 2003). The data used here corresponded to the period from December 2001 to October 2003 and to sampling locations in the vicinity of New Caledonia (Southwest of Nouméa) and around the Loyalty Islands (Loyalty Channel, Southwest of the Island of Ouvea; Santal Bay, in the Island of Lifou; and north-east of Lifou; Fig. 1). Seawater for in situ production measurements was collected between 04:00 and 04:30 h, using a rosette of twelve 81 Niskin bottles. Sampling depths were positioned every $5 \mathrm{~m}$ between the surface and $20 \mathrm{~m}$ depth, and then every $20 \mathrm{~m}$ down to a depth of 100 or $120 \mathrm{~m}$. New sterile $265 \mathrm{ml}$ plastic bottles were gently filled directly from the Niskin bottle tap. The tracer solution was prepared according to the procedure recommended by Fitzwater et al. (1982), and 185 to $370 \mathrm{kBq}$ of ${ }^{14} \mathrm{C}$-bicarbonate were added to each experimental bottle. For each experiment, 1 to several samples were inoculated with ${ }^{14} \mathrm{C}$ solution and immediately filtered in order to determine incorporation of abiotic particulate ${ }^{14} \mathrm{C}$. The in situ array was launched before sunrise and picked up at about 18:00 h. After incubation, samples were collected on $25 \mathrm{~mm} \mathrm{GF/F}$ filters using a vacuum pressure of $<50 \mathrm{hPa}$. Duplicate samples were fractionated onto $10 \mu \mathrm{m}$ polycarbonate filters by gravity alone. Filters were then processed and counted on a liquid scintillation counter according to the procedure described in detail by Le Bouteiller et al. (2003).

Experiments under simulated in situ conditions were conducted under natural light using an incubator made of Acrylite 625-5 blue Plexiglas to reduce light intensity to $30 \%$ of photosynthetically available radiation (PAR). The incubator temperature was regulated by a circulating water system. Between 6 and 10 replicate samples were taken for each experiment using new $125 \mathrm{ml}$ sterile plastic flasks; $18.5 \mathrm{kBq}$ of ${ }^{14} \mathrm{C}$-bicarbonate were added, and incubation time ranged from $30 \mathrm{~min}$ to $5 \mathrm{~h}$. After incubation, samples were processed as for in situ incubations.

Pigments. For in situ experiments using the material from the DIAPALIS cruises, $265 \mathrm{ml}$ seawater samples were filtered onto GF/F filters ( $25 \mathrm{~mm}$ in diameter) for total pigment analysis, while $577 \mathrm{ml}$ were collected for size fractionation onto $10 \mu \mathrm{m}$ polycarbonate filters. After filtration, the filters were stored in cryotubes and kept in a liquid nitrogen container. For pigment extraction, GF/F filters were dipped in a centrifuge tube containing $5 \mathrm{ml}$ of $93 \%$ acetone (the final concentration was approximately $90 \%$, after taking into account water retention in the filter), ground with a freshly broken end of a glass rod, and left in the dark at $4^{\circ} \mathrm{C}$ for a $12 \mathrm{~h}$ extraction. Polycarbonate filters were simply left in the dark at $4^{\circ} \mathrm{C}$ for $24 \mathrm{~h}$ in $5 \mathrm{ml}$ of $90 \%$ dimethyl formamide. Following extraction, the tubes were centrifuged for $5 \mathrm{~min}$ at a speed of $3500 \mathrm{rpm}$, and the fluorescence of the extracted material was measured with a HITACHI ${ }^{\circledR}$ F4500 spectrofluorometer. Concentrations of chlorophyll pigments, such as monovinylchl $a$, -chl $b$ and -chl $c(c 1+c 2 ; c 3)$, divinyl-chl $a$ and -chl $b$ and phaeopigments derived from these different chlorophylls, were assessed using a modified version of Neveux \& Lantoine's (1993) method described by Tenório et al. (2005) and Neveux et al. (2006). Only total chl a (the sum of monovinyl- and divinyl-chl a concentrations) will be considered here. The procedure for pigment analysis was similar for laboratory and simulated in situ experiments, but the sample volume was adapted to the chlorophyll content.

Trichodesmium counts. To compare the pigment content with the Trichodesmium abundance during the DIAPALIS cruises, the contents of two 81 Niskin bottles were entirely filtered in parallel: one for pig- 
ment analysis (see above) and the other for cell counts. Trichodesmium filaments were generally collected at 4 depths between 0 and $60 \mathrm{~m}$ by in-line gravity filtration onto $10 \mu \mathrm{m}$-pore size polycarbonate filters $(47 \mathrm{~mm}$ in diameter). The filters were introduced into glass vials $(25 \mathrm{ml})$ and immediately fixed by addition of a $4 \%$ formalin solution. In the laboratory, Trichodesmium filaments were recovered by washing the filters with filtered seawater and preserved with $0.4 \%$ acid formaldehyde solution. Trichodesmium filaments were counted in the whole chamber at a magnification of $100 \times$ using an inverted microscope (Olympus IM) following the Utermöhl (1958) technique.

Particulate carbon. Aliquots (5 $\mathrm{ml}$ in triplicate) of concentrated Trichodesmium cells were directly filtered onto $25 \mathrm{~mm} \mathrm{GF/F} \mathrm{filters} \mathrm{for} \mathrm{pigment} \mathrm{analysis} \mathrm{and}$ onto precombusted GF/F filters for POC analysis. The latter filters were dried at $40^{\circ} \mathrm{C}$ for $24 \mathrm{~h}$ and later kept frozen at $-20^{\circ} \mathrm{C}$ until analysis. The POC concentration was determined on a Perkin Elmer 2400 CHN analyzer.

\section{RESULTS}

\section{Photosynthesis vs. irradiance and photosynthetic quotient}

Among the 7 experiments performed with natural populations of Trichodesmium erythraeum, 4 PB vs. I curves showed a progressive increase in production $(P)$ with increasing $I$, reaching a maximum value $\left(P^{B}{ }_{\max }\right)$ at a mean PAR irradiance of about $1000 \mu \mathrm{E} \mathrm{m}{ }^{-2}$ $\mathrm{s}^{-1}$, followed by a fall in production at higher light intensity (photoinhibition). Three other curves did not exhibit any evidence of photoinhibition (Fig. 2). The

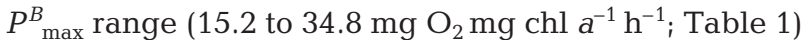
is similar to values previously reported for the Atlantic
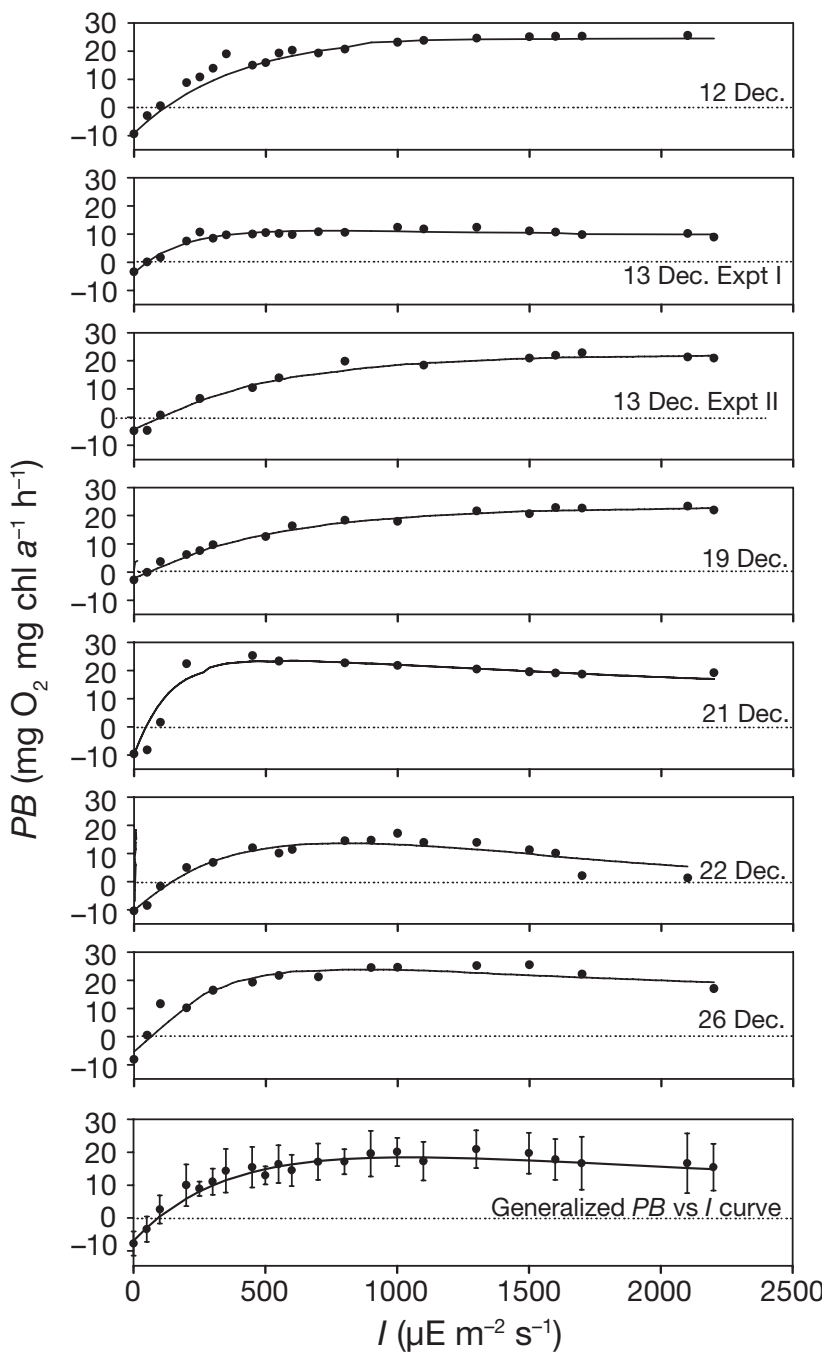

Fig. 2. Trichodesmium erythraeum. Photosynthesis vs. irradiance $(P B$ vs. $I$ ) curves; 7 curves were fitted from data points $(\bullet)$ using Platt et al.'s (1980) model. The generalized PB vs. I curve was fitted using average values of all data

Table 1. Trichodesmium erythraeum. Photosynthesis parameters estimated by means of the model of Platt et al. (1980) using 7 photosynthesis $(P B)$ vs. irradiance $(I)$ curves (Fig. 2). nd: not detected; see Eqs. (1) \& (2) in 'Materials and methods' for definitions of parameters

\begin{tabular}{|c|c|c|c|c|c|c|}
\hline Date & $\begin{array}{c}\alpha \\
\underset{\left.\mu \mathrm{E} \mathrm{mg} \mathrm{O}^{-2} \mathrm{~s}^{-1}\right)}{\left(\mathrm{mg} \mathrm{hl}^{-1} \mathrm{~h}^{-1}\right.}\end{array}$ & 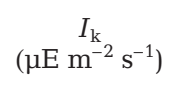 & 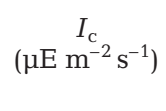 & 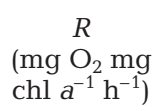 & 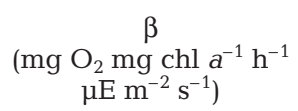 & $\begin{array}{c}P^{B}{ }_{\max } \\
\left(\mathrm{mg} \mathrm{O}_{2} \mathrm{mg}\right. \\
\left.\operatorname{chl~} a^{-1} \mathrm{~h}^{-1}\right)\end{array}$ \\
\hline $12 \mathrm{Dec}$ & 0.09 & 392 & 62 & 9.1 & nd & 34.8 \\
\hline 13 Dec Expt I & 0.09 & 169 & 48 & 3.7 & 0.001 & 15.2 \\
\hline 13 Dec Expt II & 0.06 & 461 & 93 & 4.9 & nd & 26.9 \\
\hline $19 \mathrm{Dec}$ & 0.05 & 475 & 55 & 2.8 & nd & 25.6 \\
\hline $21 \mathrm{Dec}$ & 0.25 & 135 & 63 & 9.7 & 0.006 & 34.0 \\
\hline $22 \mathrm{Dec}$ & 0.09 & 452 & 160 & 10.4 & 0.019 & 31.5 \\
\hline $26 \mathrm{Dec}$ & 0.16 & 206 & 57 & 8.1 & 0.005 & 33.6 \\
\hline Mean & 0.12 & 327 & 77 & 7.0 & 0.008 & 28.8 \\
\hline $\mathrm{SD}$ & 0.07 & 151 & 39 & 3.1 & 0.008 & 7.0 \\
\hline $\begin{array}{l}\text { Generalized } \\
P B \text { vs. } I \text { curve }\end{array}$ & 0.08 & 327 & 94 & 6.9 & 0.007 & 27.8 \\
\hline
\end{tabular}


Ocean (Carpenter et al. 1993). Most of the experiments presented a $P^{B}{ }_{\max }$ for PAR close to $1000 \mu \mathrm{E} \mathrm{m}^{-2} \mathrm{~s}^{-1}$, and one curve exhibited a $P^{B}{ }_{\text {max }}$ for PAR of $450 \mu \mathrm{E} \mathrm{m}^{-2} \mathrm{~s}^{-1}$. These $P^{B}{ }_{\max }$ values attained under strong irradiance suggest high light requirements in order to reach maximum values of photosynthesis. All experiments presented a consumption of oxygen in the dark due to respiration $(R)$. $R$ values ranged from 2.8 to $10.4 \mathrm{mg} \mathrm{O}$ $\mathrm{mg} \operatorname{chl~} \mathrm{a}^{-1} \mathrm{~h}^{-1}$ (Table 1). The light compensation index $(P=R)$ was observed for PAR ranging from 48 to $160 \mu \mathrm{E} \mathrm{m}^{-2} \mathrm{~s}^{-1}$. The ranges of values showed that these $R$ and $P$ rates can change from day to day (Fig. 2). $R$ seemed to be directly related to $P^{B}{ }_{\max }$ (Fig. 3). The decrease in production at a PAR $>1600 \mu \mathrm{E} \mathrm{m} \mathrm{m}^{-2} \mathrm{~s}^{-1}$ showed that photoinhibition can be relatively intense, up to $80 \%$ of $P^{B}{ }_{\max }$. These observations suggest that, paradoxically, photoinhibition would be relatively frequent in $T$. erythraeum present in surface waters.

Thirty experiments using natural Trichodesmium erythraeum colonies were performed under fixed conditions of temperature $\left(26^{\circ} \mathrm{C}\right)$ and irradiance $(1000 \mu \mathrm{E}$ $\mathrm{m}^{-2} \mathrm{~s}^{-1}$ ). Oxygen production and carbon fixation measured together on the same samples were closely correlated $\left(R^{2}=0.88\right)$. Data were best fitted with a linear regression (Fig. 4) with a slope of $1.191\left(\mathrm{~mol} \mathrm{O}_{2} \mathrm{~mol}\right.$ $\mathrm{CO}_{2}{ }^{-1}$ ), which corresponded to the $\mathrm{PQ}$.

The productivity varied slightly with time in the laboratory, $P B$ values being first higher and then lower than $4 \mathrm{mg} \mathrm{C} \mathrm{mg} \mathrm{chl} a^{-1} \mathrm{~h}^{-1}$ from the beginning to the end of the series (Fig. 5a). The mean calculated with all $P B$ data was $4.4 \mathrm{mg} \mathrm{C} \mathrm{mg} \mathrm{chl} a^{-1} \mathrm{~h}^{-1}(\mathrm{SD}=1.3, \mathrm{n}=30)$, with a range between 1.62 and $6.36 \mathrm{mg} \mathrm{C} \mathrm{mg} \mathrm{chl} a^{-1} \mathrm{~h}^{-1}$.

\section{Photosynthesis under simulated in situ conditions}

Experiments performed with Trichodesmium under simulated in situ conditions ( $30 \%$ of incident PAR) dis-

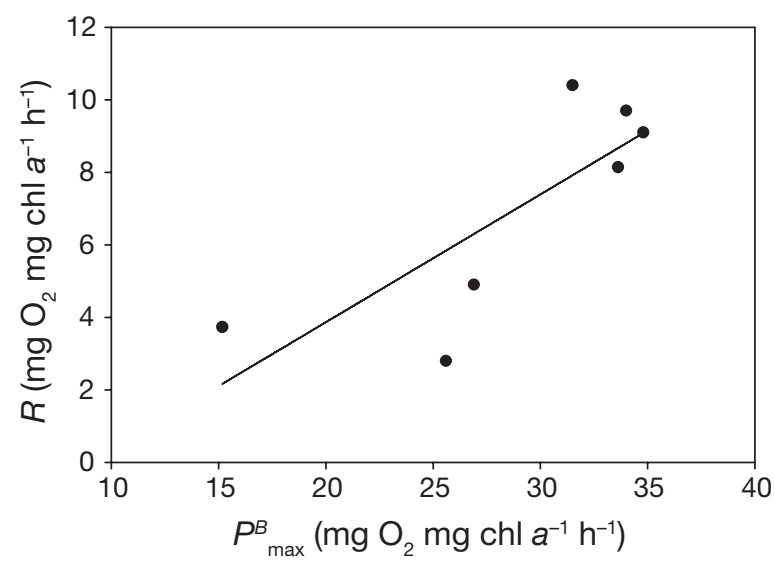

Fig. 3. Trichodesmium erythraeum. Variations in dark respiration $(R)$ with maximum photosynthesis $\left(P^{B}{ }_{\max }\right)$ played maximum $P B$ values after midday when PAR exceeded $300 \mu \mathrm{E} \mathrm{m}^{-2} \mathrm{~s}^{-1}$, and lower values in the early morning and late afternoon when PAR ranged from 100 to $200 \mu \mathrm{E} \mathrm{m}^{-2} \mathrm{~s}^{-1}$ (Fig. 5b). Hence, $P B$ was observed to be maximised for about $9 \mathrm{~h}$, i.e. almost $60 \%$ of the

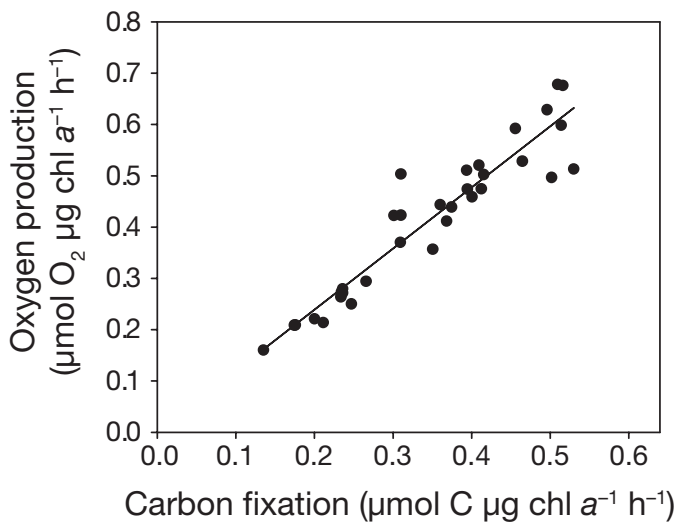

Fig. 4. Trichodesmium erythraeum. Variations in photosynthetic oxygen production with carbon fixation rate. Slope of the linear regression is photosynthetic quotient $\mathrm{PQ}(1.19 \mathrm{~mol}$ $\mathrm{O}_{2} \mathrm{~mol} \mathrm{CO}_{2}^{-1} ; \mathrm{n}=30$ )
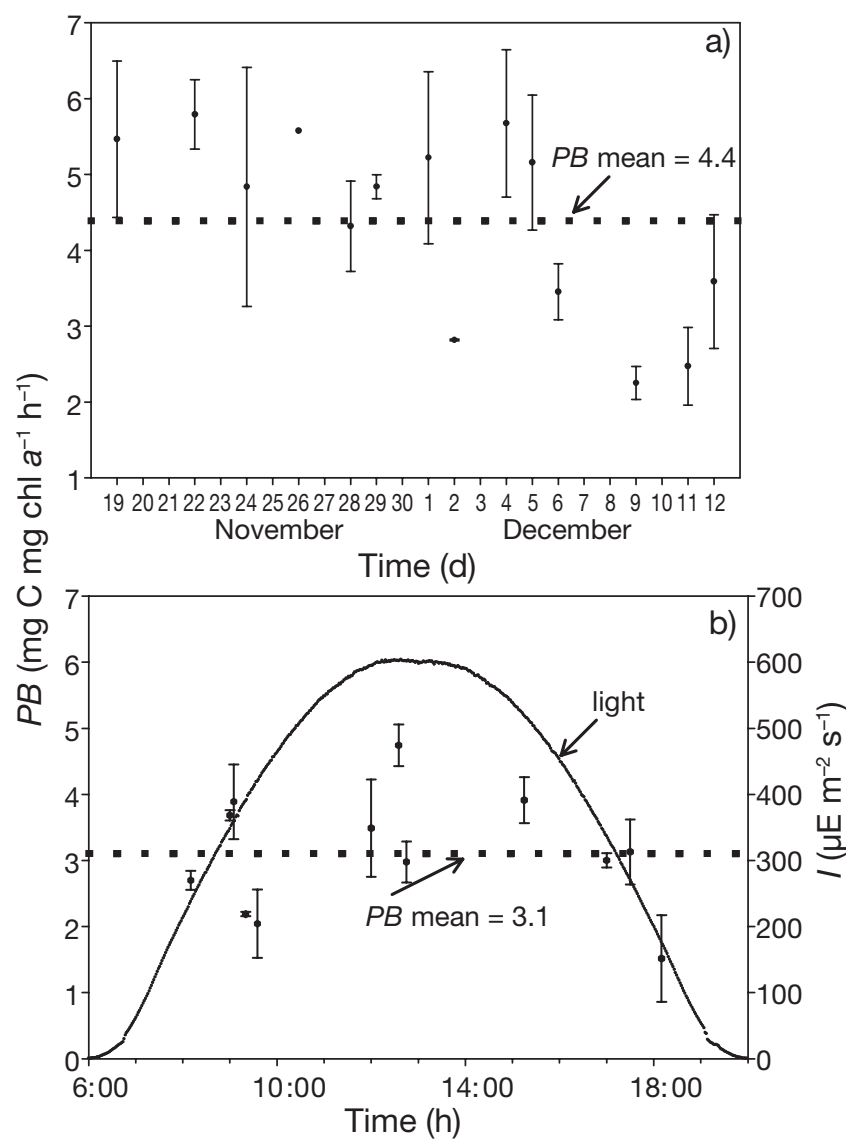

Fig. 5. Trichodesmium erythraeum. (a) Daily and (b) mean diel variations in production per unit biomass $P B$ 
summer daytime period. The mean of all $P B$ data (n = 48) was $3.1 \mathrm{mg} \mathrm{C} \mathrm{mg} \mathrm{chl} a^{-1} \mathrm{~h}^{-1}(\mathrm{SD}=0.94)$, and maximal $P B$ was $5.1 \mathrm{mg} \mathrm{C} \mathrm{mg} \mathrm{chl} a^{-1} \mathrm{~h}^{-1}$.

\section{C:chl a ratio}

The mean C:chl a ratio measured from concentrated aliquots (in triplicate) of Trichodesmium erythraeum colonies collected at the sea surface was $188 \mathrm{~g} \mathrm{C} \mathrm{g}$ chl $a^{-1}(\mathrm{SD}=52, \mathrm{n}=11$ samples). This $\mathrm{C}: \mathrm{chl}$ a ratio is especially important when calculating growth rate in terms of carbon from $\mathrm{CO}_{2}$ fixation and chlorophyll content of Trichodesmium cells.

\section{Photosynthesis under in situ conditions}

Trichodesmium abundances were determined in summer (February) at 4 depths $(0,20,40$ and $60 \mathrm{~m})$ and at 4 locations (Santal Bay, north-east of Lifou, Southwest of Ouvea and Southwest of Nouméa) and in winter (August) at 4 depths $(0,20,50$ and $80 \mathrm{~m})$ at 2 locations (Santal Bay and Loyalty Channel) (Fig. 1). In summer, the mixed layer was shallow (ca. $40 \mathrm{~m}$ ), and abundances were on average 2390 trichomes $\mathrm{l}^{-1}$ $(\mathrm{SD}=1400, \mathrm{n}=16)$ in the upper water column (0 to
$40 \mathrm{~m}$ ) and about 2-fold lower at $60 \mathrm{~m}$. The maximum value was observed at the Southwest Ouvea station (4578 trichomes $1^{-1}$ ) (Fig. 6a). In winter, the mixed layer was generally deep (100 or $120 \mathrm{~m}$ ) and abundances ranged from 38 to 76 trichomes $\mathrm{l}^{-1}$ (Fig. 6c). In the $>10 \mu \mathrm{m}$ size fraction (or Trichos biomass; Fig. 6), which mainly comprised Trichodesmium trichomes and colonies in such waters (J. Neveux pers. comm.), the summer chl a concentration ranged between 0.010 and $0.260 \mathrm{mg} \mathrm{m}^{-3}$ in the first $40 \mathrm{~m}$ (Fig. 6b). The percentage of chl $a$ in the $>10 \mu \mathrm{m}$ size fraction varied from 9 to $83 \%$ of total chl $a$ in the upper layer (0 to $40 \mathrm{~m}$ ) with a mean of $46 \%$ $(\mathrm{SD}=20 \%)$, decreasing to $6 \%$ on average at $80 \mathrm{~m}$ (Fig. 6b). Such a result suggests a frequent predominance of Trichodesmium populations in summer in the upper layer with respect to other phytoplankton species such as Synechococcus, Prochlorococcus and picoeukaryotes typical of this region, as shown by Le Bouteiller et al. (2003). In winter, chl a $(>10 \mu \mathrm{m})$ remained around $7.5 \%$ (Fig. 6d), corresponding to low Trichodesmium abundance. Summer experiments showed that, at the 4 locations, $P B$ in the $>10 \mu \mathrm{m}$ size fraction generally increased from the surface to depths of 10 or $20 \mathrm{~m}$ and then decreased with increasing depth (Fig. 7a). The mean summer maximum $P B$ (PB max) measured in situ was $3.3 \mathrm{mg}$
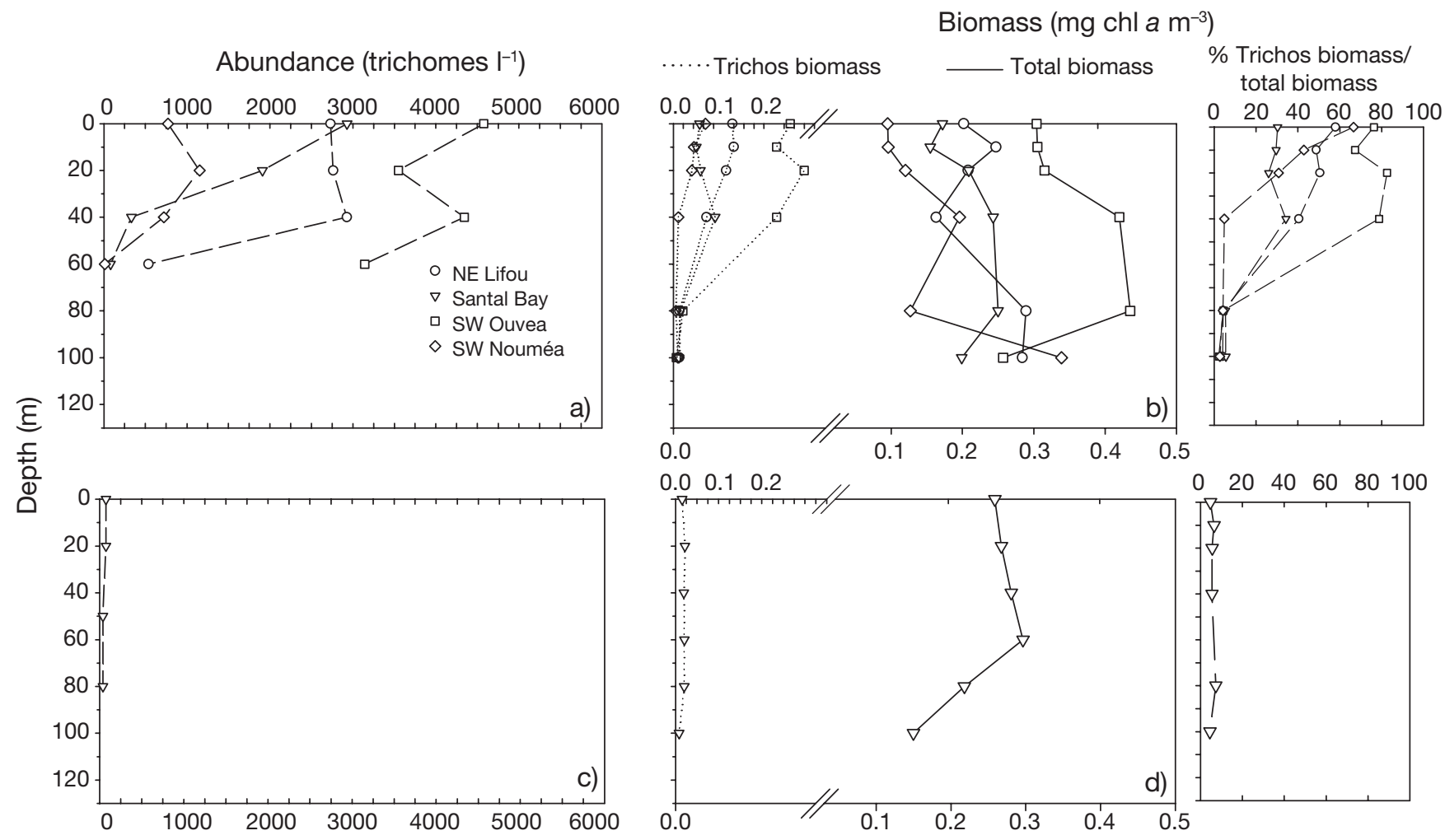

Fig. 6. Trichodesmium spp. Abundance and biomass (chl a in $>10 \mu \mathrm{m}$ size fraction, Trichos biomass) and total biomass (all phytoplankton) during (a,b) summer (February 2003) and (c,d) winter (August 2002). See Fig. 1 for sampling locations 


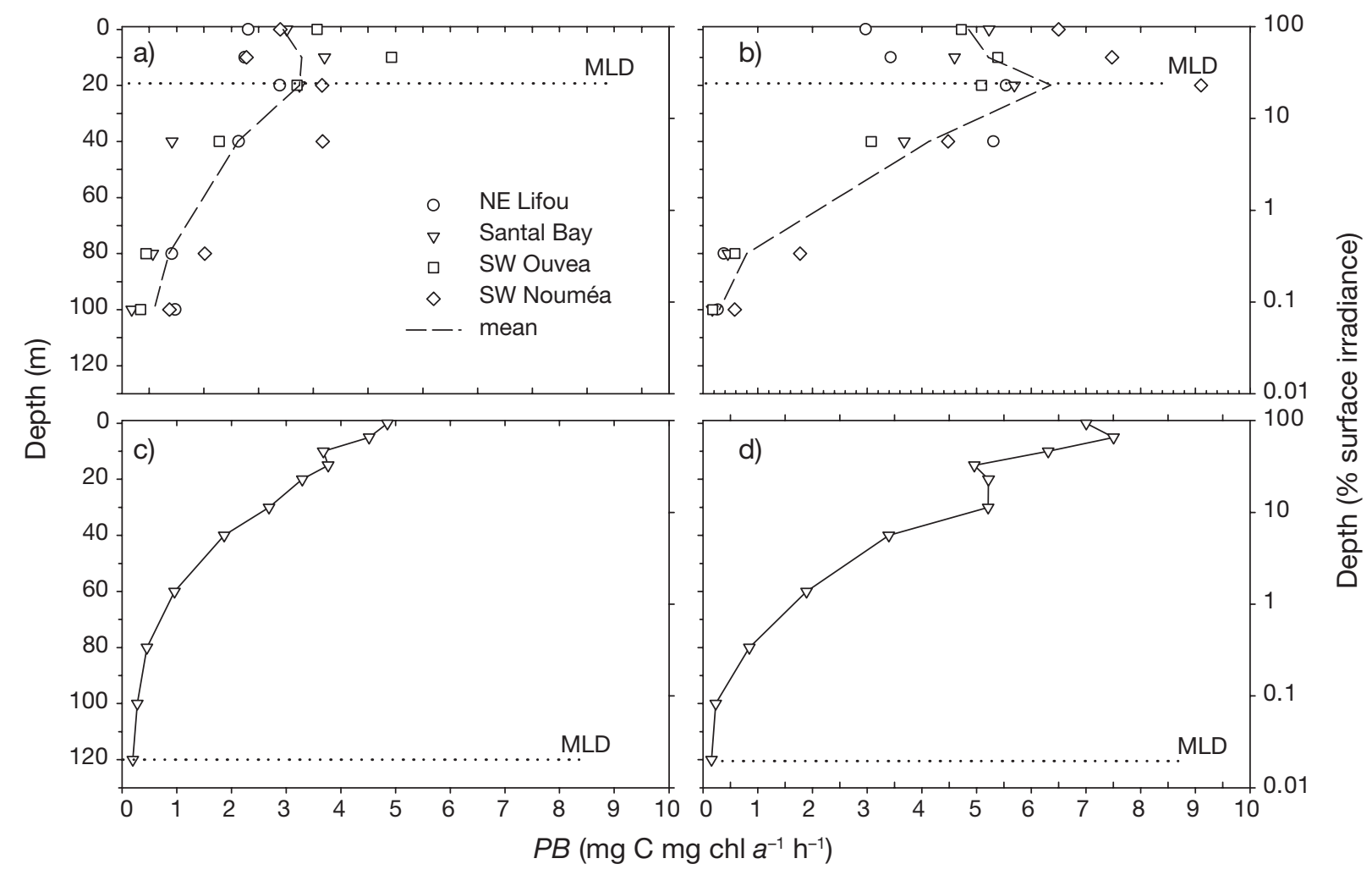

Fig. 7. In situ production per unit biomass $(P B)$ of Trichodesmium and other microphytoplankters in $(\mathrm{a}, \mathrm{b})$ summer and $(\mathrm{c}, \mathrm{d})$ winter. Mixed-layer depth (MLD; dashed line) was calculated as the depth at which water temperature differed from the sea-surface temperature by $0.4^{\circ} \mathrm{C}$ (De Boyer Montégut et al. 2004). See Fig. 1 for sampling locations

$\mathrm{C} \mathrm{mg} \mathrm{chl} a^{-1} \mathrm{~h}^{-1}$ (SD $=0.3, \sim 20 \mathrm{~m}$ depth) for temperatures above $26^{\circ} \mathrm{C}$. This PBmax should correspond to the optimal $P B$ value for Trichodesmium under in situ conditions, according to the criteria proposed by Behrenfeld \& Falkowski (1997). The relative decrease in $P B$ observed at the sea surface, and also at times at $10 \mathrm{~m}$ depth, would result from photoinhibition due to excessive available irradiance. This photoinhibition must be compared with the same process observed in the laboratory (Fig. 2). Productivity in the $<10 \mu \mathrm{m}$ size fraction presented the same pattern as in the $>10 \mu \mathrm{m}$ fraction, but $P B$ values were significantly higher (mean PBmax $=5.5 \mathrm{mg} \mathrm{C} \mathrm{mg} \mathrm{chl} a^{-1} \mathrm{~h}^{-1}$, $\mathrm{SD}=0.3)$ than in the fraction containing Trichodesmium (Fig. 7b), as previously observed in the Atlantic Ocean (Carpenter et al. 2004). In winter, Trichodesmium productivity $(>10 \mu \mathrm{m}$ fraction) displayed a PBmax of $4.9 \mathrm{mg}$ $\mathrm{C}$ mg chl $a^{-1} \mathrm{~h}^{-1}$ at or near the surface (Fig. $7 \mathrm{c}$ ). PB max in the $<10 \mu \mathrm{m}$ frac- tion varied from $7.0 \mathrm{mg} \mathrm{C} \mathrm{mg} \mathrm{chl} a^{-1} \mathrm{~h}^{-1}$ at the surface (when mean PAR $0^{+}$was as low as $1.9 \mathrm{E} \mathrm{m}^{-2}$ $\mathrm{h}^{-1}$; Table 2) to $5.0 \mathrm{mg} \mathrm{C} \mathrm{mg} \mathrm{chl} a^{-1} \mathrm{~h}^{-1}$ at $20 \mathrm{~m}$ (Fig. 7d).

Table 2. Trichodesmium spp. Optimal production per biomass ( $P B$ for size fraction $>10 \mu \mathrm{m})$ in the upper surface layer $(0-20 \mathrm{~m})$ during DIAPALIS cruises (2001-2003). Z: depth (m)

\begin{tabular}{|llccrc|}
\hline Date & Location & $\begin{array}{c}\text { PAR 0 } \\
\left(\mathrm{E} \mathrm{m}^{-2} \mathrm{~h}^{-1}\right)\end{array}$ & $\begin{array}{c}P B>10 \mu \mathrm{m} \\
\left(\mathrm{mg} \mathrm{C} \mathrm{mg} \mathrm{chl}^{-1} \mathrm{~h}^{-1}\right)\end{array}$ & $\begin{array}{c}Z \\
(\mathrm{~m})\end{array}$ & $\begin{array}{c}\mathrm{PAR}(Z) \\
\left(\mathrm{E} \mathrm{m}^{-2} \mathrm{~h}^{-1}\right)\end{array}$ \\
\hline Dec 2001 & Santal Bay & 4.20 & 4.0 & 10 & 1.47 \\
& Channel & 4.25 & 4.9 & 20 & 0.77 \\
Jan 2002 & Channel & 2.52 & 7.6 & 20 & 0.45 \\
Apr 2002 & Channel & 2.28 & 5.0 & 20 & 0.41 \\
May 2002 & Channel & 0.76 & 3.9 & 0 & 0.57 \\
& Channel & 0.76 & 3.6 & 5 & 0.38 \\
Aug 2002 & Santal Bay & 1.91 & 4.9 & 0 & 1.43 \\
& Santal Bay & 1.91 & 4.5 & 5 & 0.96 \\
Feb 2003 & NE Lifou & 3.75 & 2.9 & 20 & 0.49 \\
& Santal Bay & 3.20 & 2.8 & 20 & 0.42 \\
& Santal Bay & 2.98 & 2.1 & 10 & 1.04 \\
& Santal Bay & 3.29 & 3.7 & 10 & 1.14 \\
& SW Ouvea & 3.58 & 4.9 & 10 & 1.25 \\
& SW Nouméa & 3.49 & 2.7 & 0 & 2.62 \\
& SW Nouméa & 3.59 & 3.7 & 20 & 0.47 \\
\hline
\end{tabular}




\section{DISCUSSION}

\section{Photosynthesis vs. irradiance and the photosynthetic characteristics of Trichodesmium}

The photosynthetic characteristics $\left(P^{B}{ }_{\max }, \alpha, R, I_{\mathrm{k}}\right.$ and $I_{\mathrm{C}}$ ) observed in Trichodesmium erythraeum in the SWP are not significantly different from those reported for the North Atlantic Ocean (Table 3). $R$ was always relatively high: up to $24 \%$ of the $\mathrm{O}_{2}$ produced by photosynthesis was consumed by respiration. $P^{B}{ }_{\max }$ and $R$ both exhibited a relatively wide variation (Fig. 3), which might be inherent to process studies involving bottle incubations with variable natural communities of Trichodesmium. To perform the numerous experiments, field samples of Trichodesmium colonies may differ, for example, by different degrees of photoacclimation, depending on the various light regimes experienced previously by colonies. For instance, just before being sampled, some Trichodesmium colonies could have risen to the surface from depth by positive buoyancy (Walsby 1992), and the photosynthetic responses of such colonies are likely to differ from those of cells strongly photoacclimated to the strong irradiance in the upper water column.

Furthermore, the Trichodesmium respiration rate is known to present a marked circadian rhythm (Kana 1993, Roenneberg \& Carpenter 1993), which could have affected results because the $P B$ vs. $I$ experiments were performed at different times in the morning. The low but significant correlation between $R$ and $P^{B}{ }_{\text {max }}$ (Fig. 3) suggests that the cyanobacteria that exhibit the strongest photosynthetic capacities also have the highest respiration rate, as previously shown by Carpenter et al. (1993). Conceptually, the most photosynthetically efficient organisms, which are probably not nutrientlimited and are almost perfectly photoacclimated to the experimental conditions, would exhibit the highest respiration rate, suggesting that this intense respiration was required for optimal growth. Since rapid oxygen cycling in Trichodesmium may contribute to the protection of nitrogenase from excess $\mathrm{O}_{2}$ and simultaneously provide biochemical energy required for nitrogenase activity (Kana 1993), one may suggest that the highest photosynthetic capacities would correspond to the highest levels of diazotrophic activity.

The mean PQ obtained under saturating irradiance with natural Trichodesmium erythraeum colonies (Fig. 4) was $1.19 \mathrm{~mol} \mathrm{O}_{2} \mathrm{~mol} \mathrm{CO}{ }^{-1}(\mathrm{SD}=0.13, \mathrm{n}=30)$. According to Laws (1991), changes of PQ from 1.1 to 1.4 are a function of the $\mathrm{N}$ source for phytoplankton: the highest values reflecting a preference for $\mathrm{NO}_{3}$, and the lowest a preference for $\mathrm{NH}_{4}$. Hence, the mean PQ value found here would correspond to a slight predominance of $\mathrm{NH}_{4}$ uptake, which is in agreement with observations reported by Mulholland \& Capone (1999) that suggest that Trichodesmium communities would have a high affinity for $\mathrm{NH}_{4}$. This PQ of 1.19 is similar

Table 3. Trichodesmium. Comparative photosynthetic parameters values in the Atlantic and Pacific Oceans. 'Other species' corresponds to $T$. thieubauti and Trichodesmium spp. SD: standard deviation; $\sim$ : no data; ${ }^{*}$ : in situ PB values of Trichodesmium spp.

\begin{tabular}{|c|c|c|c|c|c|c|}
\hline \multirow[t]{5}{*}{ Parameter } & \multirow{3}{*}{\multicolumn{2}{|c|}{$\begin{array}{c}\text { Atlantic Ocean } \\
\text { Bahamas - Eastern Caribbean, } \\
\text { Sargasso Sea and Belize }\end{array}$}} & \multicolumn{4}{|c|}{ Pacific Ocean } \\
\hline & & & \multirow{4}{*}{$\begin{array}{c}\text { North } \\
\text { Pacific } \\
\text { Other species } \\
\text { Range }\end{array}$} & \multirow{4}{*}{$\begin{array}{c}\text { Simor \& Arafura Seas } \\
\text { Other species } \\
\text { Range }\end{array}$} & outh Pacific & - \\
\hline & & & & & \multirow{2}{*}{\multicolumn{2}{|c|}{$\begin{array}{c}\text { New Caledonia (this study) } \\
\text { T. erythraeum, T. spp. }{ }^{*}\end{array}$}} \\
\hline & \multirow{2}{*}{$\begin{array}{l}\text { Other species } \\
\text { Range }\end{array}$} & \multirow{2}{*}{$\begin{array}{l}\text { T. erythraeum } \\
\text { Mean (SD) }\end{array}$} & & & & \\
\hline & & & & & Range & Mean (SD) \\
\hline $\begin{array}{l}P^{B}{ }_{\max } \\
\left(\mathrm{mg} \mathrm{O}_{2} \mathrm{mg} \mathrm{chl} a^{-1} \mathrm{~h}^{-1}\right)\end{array}$ & $6.45^{\mathrm{a}}-65.7^{\mathrm{b}}$ & $36.9(18.4)$ & $\sim$ & $\sim$ & $15.2-34.8$ & $28.8(7.0)$ \\
\hline $\begin{array}{l}\alpha\left(\mathrm{mg} \mathrm{O}_{2} \mathrm{mg} \mathrm{chl}^{-1}\right. \\
\left.\mathrm{h}^{-1} \mu \mathrm{E} \mathrm{m}^{-2} \mathrm{~s}^{-1}\right)\end{array}$ & $0.019^{\mathrm{e}}-0.27^{\mathrm{b}}$ & $0.11(0.07)$ & $\sim$ & $\sim$ & $0.05-0.25$ & $0.12(0.07)$ \\
\hline $\begin{array}{l}R \\
\left(\mathrm{mg} \mathrm{O}_{2} \mathrm{mg} \mathrm{chl} a^{-1} \mathrm{~h}^{-1}\right)\end{array}$ & $4.9^{\mathrm{a}}-24.9^{\mathrm{c}}$ & $24.9(5.2)$ & $\sim$ & $\sim$ & $2.8-10.4$ & $7.0(3.1)$ \\
\hline $\begin{array}{l}I_{\mathrm{k}} \\
\left(\mu \mathrm{E} \mathrm{m}^{-2} \mathrm{~s}^{-1}\right)\end{array}$ & $142^{\mathrm{a}}-687^{\mathrm{c}}$ & 324 (216) & $\sim$ & $\sim$ & $135-475$ & 327 (151) \\
\hline 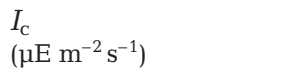 & $30-325^{\mathrm{d}}$ & $\sim$ & $\sim$ & $\sim$ & $48-160$ & 77 (39) \\
\hline $\begin{array}{l}\beta\left(\mathrm{mg} \mathrm{O}_{2} \mathrm{mg} \mathrm{chl} a^{-1}\right. \\
\left.\mathrm{h}^{-1} \mu \mathrm{E} \mathrm{m}^{-2} \mathrm{~s}^{-1}\right)\end{array}$ & $\sim$ & $\sim$ & $\sim$ & $\sim$ & $0.001-0.019$ & $0.008(0.008)$ \\
\hline $\begin{array}{l}\text { C assimilation } \\
\left(P B, \mathrm{mg} \mathrm{C} \mathrm{mg} \mathrm{chl} a^{-1} \mathrm{~h}^{-1}\right.\end{array}$ & $0.2-5^{\mathrm{f}}$ & $\sim$ & $0.38^{\mathrm{g}}-5.2^{\mathrm{h}}$ & $0.3-4.5^{\mathrm{i}}$ & $\begin{array}{l}\text { Laboratory } 1.6-6.4 \\
\text { Simul. in situ } 0.6-5.1 \\
\text { In situ* } 0.2-7.6\end{array}$ & $\begin{array}{l}4.4(1.3) \\
3.1(0.9) \\
3.3(0.3)\end{array}$ \\
\hline
\end{tabular}


to the value of 1.2 that is commonly accepted as typical for most phytoplankton (Laws 1991). However, this value of PQ is nearly 2-fold higher than those reported by Carpenter \& Roenneberg (1995) for Trichodesmium spp. in the Caribbean Sea. The PQ may be influenced by excretion of $C$ and $N$ (Laws 1991); however, we did not measure excretion in the present study. If not due to a difference in experimental protocol, such a discrepancy is difficult to account for without more information.

\section{In situ primary productivity of Trichodesmium}

In the open SWP, the vertical profiles of in situ primary productivity for the $>10 \mu \mathrm{m}$ size fraction containing Trichodesmium trichomes and colonies exhibited PBmax values that ranged from 2 to $7.6 \mathrm{mg} \mathrm{C} \mathrm{mg} \mathrm{chl}$ $a^{-1} \mathrm{~h}^{-1}$ (Table 2). Photoinhibition (ca. 10\% of PBmax) affected Trichodesmium photosynthesis in the upper water column, as determined from PAR values (Fig. 7a) that, when averaged over the daytime, exceeded about $500 \mu \mathrm{E} \mathrm{m} \mathrm{m}^{-2} \mathrm{~s}^{-1}$. This photoinhibition decreased or completely vanished in cloudy weather, especially in winter (Fig. 7c). As a consequence, PBmax generally occurred at about $20 \mathrm{~m}$ depth and rose towards the surface in response to any occasional decrease in the incident irradiance. The climatological variations of PAR present a maximum/minimum seasonal amplitude of 1.4 at the latitude of the studied region $\left(21\right.$ to $\left.22^{\circ} \mathrm{S}\right)$. Clearly, the photoinhibition evidenced both in situ and in the laboratory (Fig. 2) might dramatically affect the massive surface accumulations of Trichodesmium during blooms. In summer, as in winter, all the vertical profiles of productivity showed the same pattern, with a regular decrease in $P B$ values from $P B m a x$ to the bottom of the euphotic layer, whose depth varied between 60 and $95 \mathrm{~m}$ (Fig. 7a,c). Much the same range of values and the same variation in productivity were observed in Trichodesmium during a series of 3 cruises in the tropical North Atlantic (Carpenter et al. 2004). Similar $P B$ values were also reported from 2 days of experiments on $T$. erythraeum colonies conducted in the Timor and Arafura Seas in the western equatorial Pacific (Berman-Frank et al. 2001).

The similarity between in situ and simulated in situ productivity values suggests that, in spite of different environments (lagoon and open-ocean) and species, all Trichodesmium populations present equivalent photosynthetic performances in the region. The mean PBmax value (3.3 mg C mg chl $a^{-1} \mathrm{~h}^{-1}, \mathrm{SD}=0.3$ ) from in situ incubations did not differ significantly from results of simulated in situ experiments (PBmax $=3.1 \mathrm{mg} \mathrm{C}$ mg chl $a^{-1} \mathrm{~h}^{-1}, \mathrm{SD}=0.9$ ), whereas laboratory experiments produced a slightly higher mean PBmax (4.4 mg C mg chl $a^{-1} \mathrm{~h}^{-1}, \mathrm{SD}=1.3$ ) under optimal light and temperature conditions. PBmax observed in situ would correspond to the Trichodesmium optimal productivity under favourable light conditions, following Behrenfeld \& Falkowski's (1997) criteria. All these results lead to the conclusion that the photosynthetic capacities of Trichodesmium do not differ significantly between the Atlantic and the Pacific, and appear to be characteristic of this genus. In the future it would be interesting to consider these particular photosynthetic characteristics in the ocean models that include Trichodesmium and $\mathrm{N}_{2}$ fixation, as well as in models of carbon and nitrogen cycles.

The optimal $P B$ of Trichodesmium measured in the $>10 \mu \mathrm{m}$ size fraction (Fig. 7a,c) was generally lower than the $P B$ of the $<10 \mu \mathrm{m}$ fraction, containing nanoand picoplankton communities (Fig. 7b,d). This small fraction is mainly composed of Synechococcus, Prochlorococcus and picoeukaryotes, whose distributions in the western tropical Pacific have been described in detail by Le Bouteiller et al. (1992). The difference in PBmax between the $>10$ and $<10 \mu \mathrm{m}$ fractions may be compared with observations made in the North Atlantic: using quite different experimental procedures, Carpenter et al. (2004) found that the PBmax values of isolated Trichodesmium colonies were 2 to 4 times lower than PBmax measured in samples without colonies. They suggested that, in spite of Trichodesmium's active photosynthesis, a relatively low PBmax could be due to a weak efficiency of carbon metabolism and assimilation. This low efficiency could result from a strong excretion rate (Li et al. 1980) or a high respiration rate (Kana 1993). However, other causes of variability may explain low $P B$.

According to Laws \& Wong (1978), $P B$ may be written as the product of the fractional rate of increase in cellular $\mathrm{C}$ and the $\mathrm{C}$ :chl a ratio:

$$
P B=(1 / \mathrm{C} \times \mathrm{dC} / \mathrm{d} t)(\mathrm{C} / \mathrm{chl} a)
$$

where $\mathrm{C}$ is the cell carbon content in Trichodesmium. On average, the term ' $1 / \mathrm{C} \times \mathrm{dC} / \mathrm{d} t$ ' can be approximated by the growth rate $(\mu)$. Assuming that the $\mathrm{C}$ :chl a ratio is more or less equal in all phytoplankton subjected to the same light regime in the upper water column, then $P B$ would be positively correlated with growth rate. In the SWP, the mean C:chl a ratio of Trichodesmium sampled at the sea surface was $188 \mathrm{~g} \mathrm{C} \mathrm{g}$ chl $a^{-1}$ (SD = 52), which is not significantly different from the C:chl a ratio estimated for the $<3 \mu \mathrm{m}$ size fraction at the sea surface in the western equatorial Pacific by Le Bouteiller et al. (2003) (144 $\mathrm{g} \mathrm{C} \mathrm{g} \mathrm{chl} \mathrm{a}^{-1}, \mathrm{SD}=$ 40). As reflected by lower PBmax, Trichodesmium would have a slower growth rate than the other phytoplankters. In the SWP, the Trichodesmium growth rate was estimated as ranging between 0.18 and $0.32 \mathrm{~d}^{-1}$ 
(mean $0.21 \mathrm{~d}^{-1}$ ) in optimal light conditions, whereas $\mu$ in phytoplankton as a whole averaged $0.55 \mathrm{~d}^{-1}$ at subsurface depths in the western equatorial Pacific (Le Bouteiller et al. 2003).

\section{High light requirements for Trichodesmium growth}

Under simulated in situ conditions, the productivity of Trichodesmium was maximised when PAR exceeded $300 \mu \mathrm{E} \mathrm{m} \mathrm{m}^{-2} \mathrm{~s}^{-1}$ (Fig. 5b). This irradiance is in agreement with the photosynthetic saturation para-

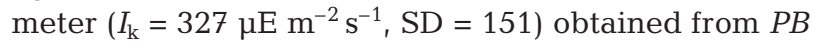
vs. $I$ experiments with $T$. erythraeum (Table 1 ). This mean $I_{\mathrm{k}}$ value is similar to those reported for Trichodesmium in previous studies conducted in the Atlantic Ocean (see Table 3; Carpenter et al. 1993, Carpenter \& Roenneberg 1995). Typically, this $I_{\mathrm{k}}$ value is much higher than the $I_{\mathrm{k}}$ for cultures of Synechococcus (range 77 to 130; Glover et al. 1987), for Prochlorococcus (range 40 to 80; Moore \& Chisholm 1999) and for picoeukaryotes (range 143 to 267; Glover et al. 1987). Field data may be used to determine at what depths such light levels are observed in the studied region. At the latitude of the study and in clear weather, the mean incident daytime irradiance PAR $0^{+}$ranges between $\sim 625$ and $1200 \mu \mathrm{E} \mathrm{m} \mathrm{m}^{-2} \mathrm{~s}^{-1}$ in winter and summer respectively. Taking these changes into account and assuming a constant mean incident radiation throughout the daytime, the mean optimal PAR of $300 \mu \mathrm{E} \mathrm{m} \mathrm{m}^{-2}$ $\mathrm{s}^{-1}$ was estimated (depending on the range of potential euphotic layer depths, which could vary from 60 to $95 \mathrm{~m}$ ) to be available at depths between 10 and $20 \mathrm{~m}$ in winter, and between 15 and $25 \mathrm{~m}$ in summer. Thus, in fine weather, the optimal depth for Trichodesmium photosynthesis in the region would be between 10 and $25 \mathrm{~m}$. In cloudy weather, and depending on cloudcover intensity and duration, this optimal light level becomes more shallow, eventually occupying the surface. In situ measurements showed that the PBmax of Trichodesmium was systematically observed at or above a depth of $20 \mathrm{~m}$, exactly as expected from results of simulated in situ and laboratory experiments.

As for $I_{\mathrm{k}}$, the depth at which the available solar radiation equalled $I_{\mathrm{C}}$ was estimated in the water column. $I_{\mathrm{C}}$ was chosen as the lowest value found in the SWP $\left(I_{\mathrm{C}}=\right.$ $48 \mu \mathrm{E} \mathrm{m} \mathrm{m}^{-2} \mathrm{~s}^{-1}$; Table 1, 13 December, Expt I). Hence, the depth at which $\mathrm{O}_{2}$ consumption by Trichodesmium respiration equals $\mathrm{O}_{2}$ production by photosynthesis is the compensation depth, and was conservatively estimated to range between $20 \mathrm{~m}$ in winter, in the case of a shallow euphotic zone $(60 \mathrm{~m})$, and $55 \mathrm{~m}$ in summer, when the euphotic zone was deepest (95 m). The application of the results of $P B$ vs. $I$ experiments to field observations leads us to conclude that the maximum depth of the photosynthetic layer for Trichodesmium is quite shallow, even without any cloud cover, and is most often between depths of 40 and $50 \mathrm{~m}$. These results suggest that Trichodesmium would not present any significant growth below a specific compensation depth situated well above the compensation depth of most other typical tropical phytoplankton species, which is classically defined as the bottom of the euphotic layer.

Field data showed that, in agreement with their photosynthetic characteristics, Trichodesmium generally predominated in the top 20 or $30 \mathrm{~m}$ layer, as also observed in the Atlantic (Carpenter et al. 2004). However, colonies were at times observed to be relatively abundant at depths of $40 \mathrm{~m}$ or even $60 \mathrm{~m}$ (Fig. 6a), i.e. at the level of or quite below the compensation depth, which is also close to the bottom of the mixed layer in summer. Although no acclimation was demonstrated at depth during the same field study (Neveux et al. 2006), some acclimation may occur in Trichodesmium colonies, allowing them to photosynthesize under conditions of low PAR. This hypothesis is supported by in situ observational data that indicated that a significant carbon fixation in the $>10 \mu \mathrm{m}$ fraction occurred at $80 \mathrm{~m}$ or even $100 \mathrm{~m}$ depth (Fig. $7 \mathrm{a}, \mathrm{c}$ ). However, this carbon fixation does not necessarily signify a positive net carbon production. The extremely low photosynthetic rate detected under a very dim light regime probably does not allow Trichodesmium to sustain any significant development of populations at a depth close to the bottom of the euphotic zone, and hence would not have any effect in the food web.

In some cases, and in spite of their potential positive buoyancy (Walsby 1992), some colonies could have been swept downward by eddy-induced convergent motions related to the circulation of the South Equatorial Current, which flows over or among the numerous seamounts and islands of the New Caledonian archipelago. Similarly, Trichodesmium colonies have been detected at depth in cyclonic eddies of the Atlantic Ocean (Davis \& McGillicuddy 2006). In addition, variable buoyancy has been put forward to explain how Trichodesmium colonies could migrate through the water column (Walsby 1992), possibly in order to mine nutrients abundant at the depth of the nutricline (Letelier \& Karl 1998). However, Trichodesmium colonies were generally observed to be scarce or totally absent at $80 \mathrm{~m}$ in the SWP, precisely at a depth where phosphate generally appears in the region (Moutin et al. 2005). On the contrary, its admittedly strong energy requirements force Trichodesmium to stay in the upper water column. Only the organisms present in this upper layer would have the capacity to succeed in cellular division in adequate time to maintain or improve the population. Furthermore, results of the present 
study are in agreement with most previous field studies in considering that the Trichodesmium growth rate, even under the best light regime, is typically slow, with at best 1 cellular division every 2 or $3 \mathrm{~d}$. Therefore, such a slow growth rate determines the time-scale of the population dynamics of Trichodesmium. To be able to proceed with cell division, Trichodesmium colonies require a strong incident radiation; in addition, such energy must be available for a long time, enough for cell division to be effective, i.e. at least 2 or 3 consecutive days. That is the reason why the vertical stratification of the water column is so important for maintaining Trichodesmium at the optimum light level for a time period sufficient for the necessary photoacclimation and cell division.

Hood et al. (2001) conceived a mathematical model that relates the seasonal variations in Trichodesmium concentration to the seasonal changes in both light availability and stratification of the water column. This model was applied to North Atlantic observations, where Trichodesmium abundance seems to be effectively higher when the mixed layer is shallower during the summer/early autumn, and where concentrations are much lower in winter/early spring when light availability is low and deep mixing occurs. Such observations suggest that the capacity of Trichodesmium to regulate its buoyancy is not sufficient to maintain trichomes at a constant light level in a turbulent mixed layer. In contrast, if the light regime is propitious over an extended time with optimal nutrient availability, cells divide and the Trichodesmium population slowly grows, and a gradual development of the biomass occurs. However, in an oligotrophic environment where all auto- and heterotrophic organisms are strongly interdependent, an increase in the biomass of a particular compartment of the food-web is only possible if the growth rate exceeds the loss rate. The loss rate of Trichodesmium due to grazing would be highly dependent on biomass, being low when colonies are scarce and potentially high during blooms (O'Neil 1998). In the SWP, concentrations of Trichodesmium are relatively low and most Trichodesmium is present as free trichomes. Furthermore, the main grazer of Trichodesmium, the copepod Macrosetella gracilis, has never been observed in the 51 samples used for counting trichomes (M. Tenório pers. comm.). The loss rate by sedimentation has been observed to be very low in the NW Pacific (Wu et al. 2003) and in the SWP, where neither Trichodesmium colonies nor specific pigment traces have been detected in sediment traps deployed during our study (M. Rodier pers. comm.). These observations suggest that, in the SWP, the loss rate due to grazing and sedimentation would be slower than the Trichodesmium growth rate, at least when the light regime is optimal in the summer period.
Acknowledgements. We thank O. Pringault, E. RochelleNewall and M. Tenório for their help with laboratory experiments. Thanks to C. Provost and the Support Committee for integrating the present study into the team programme Dynamique de l'Océan et Climat (DOC, LOCEAN). We also thank the crew of RV 'Alis' for their outstanding shipboard support for the operations at sea. This study was supported by the Institut de Recherche pour le Développement (IRD), INSU and by the French programme PROOF (PROcessus biogéochimiques dans l'Océan et Flux).

\section{LITERATURE CITED}

Behrenfeld MJ, Falkowski PG (1997) A consumer's guide to phytoplankton primary production models. Limnol Oceanogr 42:1479-1491

Berman-Frank I, Cullen JT, Shaked Y, Sherrell RM, Falkowski PG (2001) Iron availability, cellular iron quotas, and nitrogen fixation in Trichodesmium. Limnol Oceanogr 46:1249-1260

Bowman TE, Lancaster LJ (1965) A bloom of the planktonic blue-green alga, Trichodesmium erythraeum, in the Tonga Islands. Limnol Oceanogr 10:291-293

Campbell L, Carpenter EJ, Montoya JP, Kustka AB, Capone DG (2005) Picoplankton community structure within and outside a Trichodesmium bloom in the southwestern Pacific Ocean. Vie Milieu 55:185-195

Capone DG, Zehr JP, Paerl HW, Berman B, Carpenter EJ (1997) Trichodesmium, a globally significant marine cyanobacterium. Science 276:1221-1229

Capone DG, Burns JA, Montoya JP, Subramaniam A, Mahaffey C, Gunderson T, Michaels AF, Carpenter EJ (2005) Nitrogen fixation by Trichodesmium spp.: an important source of new nitrogen to the tropical and subtropical North Atlantic Ocean. Global Biogeochem Cycles 19: GB2024, doi:10.1029/2004GB002331

Carpenter EJ, Roenneberg T (1995) The marine planktonic cyanobacteria Trichodesmium spp.: photosynthetic rate measurements in the NW Atlantic Ocean. Mar Ecol Prog Ser 118:267-273

Carpenter EJ, O'Neil JM, Dawson R, Capone DG, Siddiqui PJA, Roenneberg T, Bergman B (1993) The tropical diazotrophic phytoplankter Trichodesmium: biological characteristics of two common species. Mar Ecol Prog Ser 95:295-304

Carpenter EJ, Subramaniam A, Capone DG (2004) Biomass and primary productivity of the cyanobacterium Trichodesmium spp. in the tropical N Atlantic Ocean. Deep-Sea Res I 51:173-203

Codispoti LA, Brandes JA, Christensen JP, Devol AH, Naqui SWA, Paerl HW, Yoshinari T (2001) The oceanic fixed nitrogen and nitrous oxide budgets: moving targets as we enter the anthropocene? Sci Mar 65:85-105

Davis CS, McGillicuddy DJ (2006) Transatlantic abundance of the $\mathrm{N}_{2}$-fixing colonial cyanobacterium Trichodesmium. Science 312:1517-1520

De Boyer Montégut C, Madec G, Fischer AS, Lazar A, Iudicone D (2004) Mixed layer depth over the global ocean: an examination of profile data and a profile-based climatology. J Geophys Res 109:C12003, doi:10.1029/ 2004JC002378

Dupouy C, Petit M, Dandonneau Y (1988) Satellite detected cyanobacteria bloom in the southwestern tropical Pacific. Implication for oceanic nitrogen fixation. Int $\mathrm{J}$ Remote Sens 9:389-396

Dupouy C, Dirgerg G, Tenório M, Neveux J, Le Bouteiller A (2004) Surveillance des Trichodesmium autour de la 
Nouvelle-Calédonie, du Vanuatu, de Fidji et de Tonga (1998-2004). Arch Sci Mer 7

Eppley RW, Peterson BJ (1979) Particulate organic matter flux and planktonic new production in the deep ocean. Nature 282:677-680

Fitzwater SE, Knauer GA, Martin JH (1982) Metal contamination and its effect on primary production measurements. Limnol Oceanogr 27:544-551

Glover HE, Keller MD, Spinrad RW (1987) The effects of light quality and intensity on photosynthesis and growth of marine eukaryotic and prokaryotic phytoplankton clones. J Exp Mar Biol Ecol 105:137-159

Hood RR, Bates NR, Capone DG, Olson DB (2001) Modeling the effect of nitrogen fixation on carbon and nitrogen fluxes at BATS. Deep-Sea Res II 48:1609-1648

Kana TM (1993) Rapid oxygen cycling in Trichodesmium thiebautii. Limnol Oceanogr 38:18-24

Karl D, Michaels A, Bergman B, Capone D and 6 others (2002) Dinitrogen fixation in the world's oceans. Biogeochemistry 57/58:47-98

LaRoche J, Breitbarth E (2005) Importance of the diazotrophs as a source of new nitrogen in the ocean. J Sea Res 53: 67-91

Laws EA (1991) Photosynthetic quotients, new production and net community production in the open ocean. DeepSea Res 38:143-167

Laws EA, Wong DC (1978) Studies of carbon and nitrogen metabolism by three marine phytoplankton species in nitrate-limited continuous culture. J Phycol 14:406-416

Le Bouteiller A, Blanchot J, Rodier M (1992) Size distribution patterns of phytoplankton in the western Pacific: towards a generalization for the tropical open ocean. Deep-Sea Res 39:805-823

Le Bouteiller A, Leynaert A, Landry M, Le Borgne R, Neveux J, Rodier M, Blanchot J, Brown SL (2003) Primary production, new production, and growth rate in the equatorial Pacfic: changes from mesotrophic to oligotrophic regime. J Geophys Res 108:8141, doi:101029/ 2001J000914

Letelier RM, Karl DM (1998) Trichodesmium spp. physiology and nutrient fluxes in the North Pacific subtropical gyre. Aquat Microb Ecol 15:265-276

Li WKW, Glover HE, Morris I (1980) Physiology of carbon photoassimilation by Oscillatoria thiebautii in the Caribbean Sea. Limnol Oceanogr 25:447-456

Mague TH, Mague FC, Holm-Hansen O (1977) Physiology and chemical composition of nitrogen-fixing phytoplankton in the central North Pacific Ocean. Mar Biol 41: 213-227

Moore LR, Chisholm SW (1999) Photophysiology of the marine cyanobacterium Prochlorococcus: ecotypic differences among cultured isolates. Limnol Oceanogr 44: 628-638

Moutin T, Van den Broeck N, Beker B, Dupouy C, Rimmelin P, Le Bouteiller A (2005) Phosphate availability controls Trichodesmium spp. biomass in the SW Pacific Ocean. Mar Ecol Prog Ser 207:15-21

Mulholland MR, Capone DG (1999) Nitrogen fixation, uptake and metabolism in natural and cultured populations of Trichodesmium spp. Mar Ecol Prog Ser 188:33-49

Editorial responsibility: Alain Vézina (Contributing Editor), Dartmouth, Nova Scotia, Canada
Mulholland MR, Floge S, Carpenter EJ, Capone DG (2002) Phosphorus dynamics in cultures and natural populations of Trichodesmium spp. Mar Ecol Prog Ser 239:45-55

Nakayama E, Obata H, Okamura K, Isshiki K, Karatani H, Kimoto T (1995) Iron and manganese in the atmosphere and oceanic waters. In: Sakai H, Osaki N (eds) Biogeochemical processes and ocean flux in the western Pacific. Terra Scientific Publishing Company (TERRAPUB), Tokyo, p 53-68

Neveux J, Tenório M, Dupouy C, Villareal TA (2006) Spectral diversity of phycoerythrins and diazotroph abundance in tropical waters. Limnol Oceanogr 51:1689-1698

O'Neil JM (1998) The colonial cyanobacterium Trichodesmium as a physical and nutritional substrate for the harpacticoid copepod Macrosetella gracilis. J Plankton Res 20:43-59

Platt T, Gallegos CL, Harrison WG (1980) Photoinhibition of photosynthesis in natural assemblages of marine phytoplankton. J Mar Res 38:687-701

Revelante N, Gilmartin M (1982) Dynamics of phytoplankton in the Great Barrier Reef lagoon. J Plankton Res 4: $47-76$

Roenneberg T, Carpenter EJ (1993) Daily rhythm of $\mathrm{O}_{2}$-evolution in the cyanobacterium Trichodesmium thiebautii under natural and constant conditions. Mar Biol 117: 693-697

Shimura S, Yamaguchi Y, Aruga Y, Fujita Y, Ichimura S (1978) Extracellular release of photosynthetic products by a pelagic blue-green alga, Trichodesmium thiebautii. J Oceanogr Soc Jpn 34:181-188

Sournia A (1968) La cyanophycée Oscillatoria (= Trichodesmium) dans le plancton marin. Nova Hedwigia 15: $1-12$

Tenório MB, Le Borgne R, Rodier M, Neveux J (2005) The impact of terrigeneous inputs on the Bay of Ouinné (New Caledonia) phytoplankton communities: a spectrofluorometric and microscopic approach. Estuar Coast Shelf Sci 64:531-545

Utermöhl H (1958) Zur Vervollkommnung der quantitativen Phytoplankton-Methodik. Mitt Int Ver Limnol 9:1-38

Van den Broeck N, Moutin T, Rodier M, Le Bouteiller A (2004) Seasonal variations of phosphate availability in the SW Pacific Ocean near New Caledonia. Mar Ecol Prog Ser 268:1-12

Villareal TA (1995) Abundance and photosynthetic characteristics of Trichodesmium spp. along the Atlantic Barrier Reef at Carrie Bow Cay, Belize. PSZN I: Mar Ecol 16: $259-271$

Walsby AE (1992) The gas vesicles and buoyancy of Trichodesmium. In: Carpenter EJ, Capone D, Rueter J (eds) Marine pelagic cyanobacterium: Trichodesmium and other diazotrophs. Kluwer Academic, Dordrecht, p 141-162

Wu J, Sunda W, Boyle EA, Karl DM (2000) Phosphate depletion in the western North Atlantic Ocean. Science 289: 759-762

Wu J, Chung SW, Wen LS, Liu KK, Lee Chen YL, Chen HY, Karl DM (2003) Dissolved inorganic phosphorus, dissolved iron, and Trichodesmium in the oligotrophic South China Sea. Global Biogeochem Cycles 17:1008, doi:10.1029/ 2002GB001924

Submitted: May 12, 2006; Accepted: October 2, 2006 Proofs received from author(s): May 4, 2007 